\title{
Az alkotmányozás dilemmái - 10 év múltán
}

TRÓCSÁNYI LÁSZLÓ ${ }^{1}$

„Magyarország új Alaptörvénye viharban született.” Jogi és politikai szenvedélyek viharában. Az Alaptörvény születését övezö viták természetes következményei lettek volna bármely olyan új alkotmánynak, amely olyan államban születik, amely az EU-csatlakozást követöen (a 2004-ben újonnan csatlakozott tagállamok közül elsőként) vállalkozik ilyen feladatra. A 2010-ben megindult magyar alkotmányozás egyfajta minilaboratóriumi közeg volt. Az Európai Unió egyes intézményeinek, demokrácia-központú figyelmének a középpontjába kerültünk. Ezenfelül, Magyarország esetében azt láthattuk, hogy szinte valamennyi jelentös nemzetközi szervezet (ENSZ, Európa Tanács) úgy vélte, hogy véleményt kell formálniuk a magyar Alaptörvényröl.

Kulcsszavak: alkotmányozás, nemzetközi szervezetek, kritika, Alaptörvény, Velencei Bizottság, Európai Unió, Európai Bizottság, Európai Parlament, demokrácia, történeti alkotmány, alkotmánymódosítás, alkotmányozó hatalom

\section{The Dilemmas of Constitution-making - After 10 Years}

"The new Fundamental Law of Hungary was born in a storm." In the storm of heavy legal and political sentiments. The debates surrounding the birth of the Fundamental Law would have been a natural consequence of any new constitution being born in a state that undertook such a task after EU accession (the first of the new Member States that joined in 2004). The Hungarian constitution-making, which started in 2010, was a sort of mini laboratory medium. We landed in the centre of the democracy-focused attention of some of the institutions of the European Union. In addition, we have seen that almost all significant international organisations (UN, Council of Europe) considered that they should form an opinion on the Hungarian Fundamental Law.

1 EP-képviselő, egyetemi tanár, Szegedi Tudományegyetem Állam- és Jogtudományi Kar; a Velencei Bizottság tagjaként számos európai alkotmányjogi kérdésben folytatott nemzetközi vizsgálat tanúja volt, többek között a magyar Alaptörvény vonatkozásában is.

2 Trócsányi László: Nemzeti alkotmányok, európai integráció és alkotmányos identitás. In Tóth Judit (szerk.): Tanulmányok Dr. Tóth Károly címzetes egyetemi tanár 70. születésnapjára. Szeged, Szegedi Tudományegyetem, 2015. 323.

3 Trócsányi (2015). i. m. 
Keywords: constitution-making, international organisations, criticism, Fundamental Law, Venice Commission, European Union, European Commission, European Parliament, democracy, historical constitution, constitutional amendment, constitution-making power

\section{Bevezető}

Amikor a magyar Alaptörvény tíz évéről kell véleményt mondanom, akkor egyszerre három minőségemben kívánok fogalmazni. Egyrészt, mint az alkotmányjog profeszszora és volt alkotmánybíró, másrészt mint egykori diplomata, harmadsorban pedig mint volt igazságügyi miniszter. Mindhárom minőségemben tanúja lehettem az új alkotmánnyal - az Alaptörvénnyel - kapcsolatos vitáknak.

Egyetemi oktatói, professzori, majd alkotmánybírói szerepkörben átélhettem az 1949. évi XX. törvény, az ideiglenes alkotmány agóniáját. Előadásaimban sokat beszéltem a korábbi alkotmány ideiglenes jellegéről, értéksemlegességéről, alkotmánybíróként pedig igyekeztük az alkotmányos rendet védeni akkor is, amikor a Magyar Közlöny tudatosan olyan „ünnepi számot” jelentetett meg 2009. október 23-án, amely az alkotmány megcsúfolását jelentette. ${ }^{4}$ Mindazonáltal a korábbi alkotmány teljesítette azt a feladatát, hogy a rendszerváltozás sikeresen megtörténjék Magyarországon. Az új alkotmány megszületését hosszú vívódás előzte meg, amelyet majd alább részletesen kifejtek.

Diplomataként, a párizsi magyar nagykövet székéből szembesültem azzal, hogy egy értetlen nemzetközi közösséggel kell megértetnem azokat az értékválasztásokat, amelyek az addig megszokott mainstream kánonnal adott esetben szembementek, az új Alaptörvény például a történeti alkotmánnyal, határon túli nemzettestekkel, házasság- és családfogalommal összefüggő rendelkezései kapcsán. Ha tetszik, ellenséges közegben kellett védelmembe vennem az alkotmányt. Pár évvel később, a viták már javában folytak az Alaptörvény nagy vihart kavart negyedik módosítása kapcsán, amikor a párbeszéd híveként, Martonyi János akkori külügyminiszter felkérésére több nemzetközileg elismert jogtudóst kértem fel egy szakvélemény megfogalmazására.

Azért felütésként említem mindezt az értékelés elején, mert a három profeszszor ${ }^{5}$ által adott szakvéleménnyel homlokegyenest eltérő véleményt fogalmazott meg a Velencei Bizottság a mindkét grémium által elemzett alkotmányi rendelkezésekről.

$4 \quad$ Vö. Trócsányi László: Az alkotmányozás dilemmái. Alkotmányos identitás és európai integráció. Budapest, HVG-ORAC, 2014. 39.

5 Pierre Delvolvé, Paris 2 Panthéon-Assas professzora, Eivind Smith az oslói egyetem professzora, és Francis Delpérée a Louvain-la-Neuve-i Katolikus Egyetem emeritus professzora. 
Mindez még ma is azt jelenti számomra, hogy óvatosnak kell lenni az értékítéletekkel, így a nemzetközi szervezetek véleményeit is kritikai szemlélettel kell befogadni. ${ }^{6}$ Az Alaptörvény első éveinek értékelése során még egy-két részletre ezzel kapcsolatban kitérek majd alább is.

Harmadik minőségemben, igazságügyi miniszterként, még az előbbieknél is közelebb kerültem az alkotmányhoz, nem a tanítása, értelmezése vagy magyarázata volt a feladatom, hanem azoknak a szabályozásoknak az előkészítése, amelyek a hazai joggyakorlatban és a nemzeti és nemzetközi biztonság területén azonosított különleges körülményekre való reakcióként két módosításban (hatodik és hetedik) öltöttek testet. Ezekről is fogok néhány szót szólni majd az alábbi értékelés részeként.

Korábbi írásaimban, felszólalásaimban mindig azt hangoztattam, hogy még nem telt el elegendő idő ahhoz, hogy az Alaptörvénnyel életbe léptetett alkotmányos rendet, az „alkotmány gyakorlatát” értékelhessük. Az Alkotmány Jakab András-féle 2009-es kommentárjában szerzőtársammal - Sulyok Mártonnal - együtt az 1989-es alkotmányozás összefüggéseiben úgy fogalmaztunk, hogy az alkotmányozásnak is rendelt ideje van, ${ }^{7} \mathrm{~s}$ így rendelt ideje van az értékelésnek is. Az Alaptörvény „tízéves” születésnapja is egy ilyen rendelt idő.

Az alkotmányozással kapcsolatban felmerülő számomra legfontosabb dilemmákról először 2014-ben értekeztem egy hosszabb monográfia keretében, ${ }^{8}$ értékelve az alkotmányjog régi fogalmainak új tartalmát (szuverenitás, demokrácia, hatalommegosztás, alapjogvédelem), az alkotmányozás menetét, az alkotmány stabilitásának és módosításának kérdéseit, valamint az EU és az ET intézményrendszerével folytatott párbeszédben érintett fontosabb közjogi kérdéseket.

Az Alaptörvény (At.) értékelésére elfogadásának ötödik évfordulóján tettem elöször kísérletet, akkor azt mondtam, hogy bár öt év nem hosszú idő, „mégis alkalmas arra, hogy megálljunk, megnézzük, hogy meddig jutottunk. Tanuljunk a vitákból, a dilemmákra közösen keressük a megoldást.” 2016-ban ismét megállásra kényszerültem, amikor az addig eltelt igen eseménydús két év eredményeivel és tapasztalataival ismét végeztem egy helyzetértékelést. ${ }^{10}$

6 A három professzor véleményét $A z$ alkotmányozás dilemmái címủ könyvem melléklete tartalmazza magyar nyelven.

7 Sulyok Márton - Trócsányi László: Preambulum. In Jakab András (szerk.): Az Alkotmány kommentárja. 2. kiadás, Budapest, Századvég, I. kötet, 2009. 52-60.

8 Trócsányi (2014) i. m.

9 Trócsányi László: Az Alaptörvény értékrendje. In Vízkelety Mariann (főszerk.): 5 éves az Alaptörvény. Válogatás az ünnepi konferenciasorozat beszédeiből. Budapest, Magyar Közlönyés Lapkiadó, 2017. 108.

10 László Trócsányi: The Dilemmas of Drafting the Hungarian Fundamental Law. Constitutional Identity and European Integration. Passau, Schenk Verlag, 2016. Ebben az évben egyébként hasonló értékelést, számadást végzett az At. rendelkezéseivel kapcsolatban kialakult gyakorlatról és kapcsolódó elméleti tételekről az SZTE ÁJTK oktatói kara egy 38 tanulmányt felvonultató számadásban. Lásd: Balogh Elemér (szerk.): Számadás az Alaptörvényröl. Budapest, Magyar Közlönyés Lapkiadó Kft., 2016. 
A jelen sorok, ezúttal négy év után, köszönettel az erre irányuló szerkesztői felkérésnek is, arra szolgálnak tehát, hogy az At. elfogadása óta eltelt tizedik év végén értékeljem azokat a körülményeket és vitákat, amelyek a magyar alkotmány jelenlegi tartalmához és formájához vezettek. Értelemszerűen a jelen írásban az At. „törzsszövege", annak koncepciója és az ahhoz az elfogadást és hatálybalépést követően füzött egyes módosítások kapcsán felvetődő fontosabb vitakérdéseket és ezek magyarázatait tekintem át.

Természetesen minden értékelésre hatással van az értékelő nézőpontja és szubjektuma, és úgy vélem, hogy az At. megítélésében nem kerülhetem meg azokat a nemzetközi vitákat, amelyek visszahatottak saját nézőpontjaimra is, és amelyeket közelebbről is volt alkalmam átélni nagyköveti, majd később igazságügyi miniszteri tisztségeimben.

„Magyarország új Alaptörvénye viharban született.” - írtam korábban. ${ }^{11}$ Sőt azt is mondhatnám, hogy jogi és politikai szenvedélyek viharában. E viharos viták természetesen abból az adottságból következtek, amely feltehetően bármely olyan ország új alkotmányát jellemezte volna, amely az EU-csatlakozást követően szánja el magát (elsőként az újonnan csatlakozott tagállamok közül) az Alaptörvény elfogadásához hasonló feladatra: egy új alkotmány létrehozására.

A 2010-ben megindult magyar alkotmányozás egyfajta minilaboratóriumi közeg volt, számos nemzeti és nemzetközi mikroszkóp fordult felénk. Az Európai Unió egyes intézményei (Bizottság, Európai Parlament) demokrácia-központú figyelmének a központjában - hatáskör hiányában is - a volt szovjet befolyás alatt álló országok állnak, Magyarország esetében pedig ez különösen igaz 2010 óta. Joggal vethető fel a kérdés, hogy egy nemzeti alkotmány megalkotása mennyire egy független országnak a „belügye”, és mennyiben van abba beleszólási joguk külső erőknek. Magyarország esetében azt láthattuk, hogy szinte valamennyi jelentős nemzetközi szervezet (ENSZ, Európa Tanács, Európai Unió) úgy vélte, hogy véleményt kell formálniuk a magyar Alaptörvényről. Elsőként a Velencei Bizottság ${ }^{12}$ (amelynek akkor még tagja voltam), majd később az Európai Parlament (amelynek most tagja vagyok) vizsgálta kritikai éllel az Alaptörvény (At.) elfogadását és az elfogadás körülményeit, az ahhoz vezető utat. $^{13}$

Egy állam alkotmánya az ország jogi, társadalmi és gazdasági alaprendjének legfontosabb dokumentuma, amely saját szuverenitása körében szabadon végzett „alkotmánymérnökösködéssel" (constitutional engineering) fogadhat el, azzal kapcsolatban a nemzetközi figyelem tipikusan már annak elfogadott állapotában, normaként érvényesül, mondjuk a Velencei Bizottság által végzett alkotmányos tanácsadás

11 Trócsányi (2015) i. m. 323.

12 CDL-AD(2011)001 (28 March 2011) on Three Legal Questions Arising in the Process of Drafting the New Constitution of Hungary and CDL(2011)032 (6 June 2011) Draft Opinion on the New Constitution of Hungary.

13 Lásd pl.: European Parliament: European Parliament resolution of 5 July 2011 on the Revised Hungarian Constitution. vagy az ún. European Parliament: Tavares Report. 2013. 
(constitutional assistance) keretében..$^{14}$ Ezen alkotmányos tanácsadási tevékenység is legtöbbször abból indul ki, hogy a megértés szándékával feltérképezi a norma születéséhez vezető utat és a történeti kontextusokat, ha azok befolyással lehettek annak keletkezésére. Magyarország esetében a Velencei Bizottság azonban nemcsak az At. elfogadásának körülményeit vizsgálta, hanem kritikai éllel viszonyult annak egyes cikkeihez is. Mint a Velencei Bizottság egykori tagja jómagam mindig óvatos voltam, amikor egy konkrét országot alkotmányának módosítására szólított fel a Velencei Bizottság. ${ }^{15} \mathrm{Az}$ alkotmányozó hatalom forrása ugyanis a nép, ezért a nemzetközi szervezeteknek csak azt lehet vizsgálniuk, hogy egy ország alkotmánya nem sért-e nemzetközi kötelezettségvállalásokat (például kisebbségvédelem).

Mindezen bevezetés után röviden tekintsük át azt a történeti kontextust ${ }^{16}$ - ezúttal 1989 utánra vonatkoztatva -, amely az At. elfogadásához vezetett.

\section{Prológus - Máig élő történelem?}

A rendszerváltáskori magyar alkotmányozás sajátossága volt - talán a „tárgyalásos forradalom" során is tanúsított és magyaroktól nem idegen „fontolva haladás” eszméje által vezérelve -, hogy az érintett szereplők nem teljesen új alkotmány elfogadása mellett döntöttek, ezzel egyedüliként maradva az ekkor már posztszovjet kelet-közép-európai országok között.

A NEKA-tárgyalások (Nemzetközi Kerekasztal) eredményeként tulajdonképpen egy (legitimációs krízissel küzdő) ${ }^{17}$ extraparlamentáris alkotmányozás valósult meg, amely megteremtette a legfontosabb alkotmánybiztosítékokat, létrehozta - többek között - az államfői tisztséget és az Alkotmánybíróságot. E folyamat eredményeit az első szabadon választott parlament pusztán megerősítette, jóváhagyta - azonban meghagyta az 1949-es alkotmány számozását, talán a kontinuitás hangsúlyozásának szándéka által vezérelve. Az alkotmány megfelelt az európai standardoknak, de nem kívánt válaszolni arra a kérdésre, hogy kik vagyunk, honnan jöttünk és merre tartunk, mi a helyünk a világban. Azaz a társadalmi kohézió erősítését nem tudta szolgálni. Ezenfelül az alkotmányra nehezedett a rendszerváltás szimbolikus terhe

14 Maartje de Visser: A Critical Assessment of the Role of the Venice Commission in Processes of Domestic Constitutional Reform. American Journal of Comparative Law, 63. (2015), 4. 963-1008.

15 CDL-AD(2013)018-e, Opinion on the balance of powers in the Constitution and the Legislation of the Principality of Monaco. 2013.

16 Hosszabban lásd: László Trócsányi - Márton Sulyok: The Birth and Early Life of the Basic Law of Hungary. In András Zs. Varga - András Patyi - Balázs Schanda (eds.): The Basic (Fundamental) Law of Hungary: A Commentary of the New Hungarian Constitution. Clarus Press, 2015. 1-10.

17 Mivel hazánkban az alkotmányozó és törvényhozó hatalom nem különül el egymástól, így a rendszerváltás idején a NEKA legitimációs krízise abból fakadt, hogy nem volt szoros értelemben vett felhatalmazásuk az alkotmányozásra, és formailag végül az első szabadon választott országgyűlés fogadta el a módosításokat. Az alkotmány elfogadásával kapcsolatos legitimációs deficit kérdése - elsősorban politikai aspektusból - természetesen az At. kapcsán is felmerült számos alkalommal, de jogi értelemben véve az At. szövegének kidolgozása, megvitatása és elfogadása parlamenti keretek között, az alkotmányozó hatalom által történt. 
is, nevezetesen, hogy preambulumában önmagát deklarálta ideglenesnek azzal, hogy „az új Alkotmány elfogadásáig” szólt.

A régi és az új politikai elit osztozott abban a téves feltevésben, hogy képesek lesznek a rendszerváltást követően egy ilyen új alkotmányt elfogadni, és erre nem is került sor - kompromisszumok ellenére (például 119/1996 [XII. 21.] OGY határozat a Magyar Köztársaság új alkotmányának szabályozási elveiről) sem - a pártok közötti megegyezés hiánya okán. Ennek is köszönhető az, hogy az 1990 és 2010 közötti időszakban az alkotmányozás ügye változó intenzitással ugyan, de folyamatosan belső viták tárgyát képezte.

1990 és 1994 között a szükséges többség hiányában, valamint a rendszerváltozás miatt szükséges jogalkotási dömping miatt nem is lehetett érdemi előrelépés az alkotmányozás ügyében. 1994 és 1998 között pedig baloldali kétharmados többségű törvényhozás mellett felállt az első alkotmány-előkészítő parlamenti bizottság. Az alkotmányozást azonban a pártok közötti konszenzus megszűnése miatt (MSZP-SZDSZ ellentét) ismét nem rendezték. 1998 és 2002 között a jobbközép Orbán (I) kormány nem rendelkezett a kétharmados alkotmányozó többséggel, és az alkotmányozás addigi kudarcai miatt megváltozott belpolitikai klímában pusztán a szent istváni államalapítás emlékéről szóló 2000. évi I. törvény elfogadása és az ebben kifejtett történeti narratíva jelezte azt, hogy az új alkotmány elfogadása nem elfeledett ügy. Ekkortájt következett be az a változás is, hogy a rendszerváltáskor felállott Alkotmánybíróság által addig épített „láthatatlan alkotmány" ${ }^{18}$ helyett egy normatívabb megközelítés kezdte jellemezni a testület működését, talán tekintettel az összetételében bekövetkezett változásokra is.

A 2002 és 2010 közötti baloldali kormányok ciklusai alatt voltak ugyan óvatos kísérletek az alkotmányozásra, de a konszenzus továbbra is fennálló hiányában nem rendelkeztek az elfogadáshoz szükséges parlamenti többséggel. Míg az ezt megelőző időszakokban a kancellárdemokrácia természetének megfelelően a miniszterelnök közhatalmi szerepe volt hangsúlyosabb, addig ebben a periódusban az „elnöki hatalom" és tekintély, értsd az államfői pozíció hangsúlyai voltak erősebbek (Mádl Ferenc óvatosan, Sólyom László személyében erőteljesen), akik túlterjeszkedtek elődeik és utódaik az „államszervezet demokratikus müködése felett őrködő” archetípusain. Ezen időszak egy részében az Alkotmánybíróság tagjaként részese lehettem számos olyan döntésnek, amelynek szellemisége az Alkotmánybíróság első ciklusa időszakának döntéseit vette alapul.

Ezzel a kettős aktivizmussal együtt ébredt fel ismét az alkotmányozás szele, tekintettel arra a 2000-es évek közepén tapasztalható politikai, gazdasági és morális krízisre, amely ekkoriban volt tapasztalható. Az 1949-évi XX. törvény egyre kevésbé

18 Létrejöttekör a láthatatlan alkotmány koncepciója Sólyom László elhíresült párhuzamos indokolásában a halálbüntetést alkotmányellenessé nyilvánító 23/1990 (X.31) AB határozatban maga is utalt egyébként hazánk új alkotmányának elfogadására, és arra, hogy a láthatatlan alkotmány „az alkotmányosság biztos mércéjéül szolgál; és ezért várhatóan a meghozandó új alkotmánnyal, vagy jövőbeli alkotmányokkal sem kerül ellentétbe”. 
jelentett nyugalmi helyzetet, érlelődött egy új alkotmány elfogadásának szükségessége. A 2010. áprilisi parlamenti választások révén alkotmányozó parlamenti többséget szerző jobboldali kormánykoalíció pedig beváltotta azt az ígéretét, hogy választási győzelem esetén nekilát hazánk új alkotmánya elfogadásának, amelyet végül 2011. április 25-én írt alá a köztársasági elnök, egy héttel annak elfogadását követően.

Az alkotmányozás módszertana formátumában ugyan hasonlított a NEKA munkabizottságok felépítésére és szerkezetére, de természetesen már a 1994-1998 közötti módszerrel, eseti parlamenti bizottság felállításával indult meg a munka, amely nem egész egy év alatt el is készítette az alkotmány szabályozási elveit (2010. június 29 - 2011. március 11.). 2011. április 18-án pedig az Országgyűlés elfogadta Magyarország Alaptörvényét.

A nemzetközi figyelem és viták első fókusza a fentiek kapcsán a folyamat meglehetősen rövidnek ítélt időtartama volt. Az azonban biztos, hogy ebben az időszakban nemcsak a nemzeti szinten, de a nemzetközi szinten is megnövekedett figyelem irányult a magyar alkotmányozás ügyére tudományos konferenciákon keresztül. Az új At. számos rendelkezése az érdeklődés homlokterébe került, azonnal látható volt, hogy az alkotmány szellemiségében el kíván térni a II. világháborút és elsődlegesen az 1968-as párizsi diáklázadást követő időszak nemzeti alkotmányainak nézeteitől. Egyszerre sokkolta és mozgósította az At. a nemzetközi szervezeteket (EU, ENSZ, EBESZ és nemzetközi nem kormányzati szervezeteket), így az új magyar alkotmány ügye európai-nemzetközi üggyé vált. Többen éltek kritikával, mint elismeréssel. A támadásoknak, kritikáknak alapvetően ideológiai természetük volt, miután az államszervezet alapvetően nem változott.

Ami a folyamat érdekessége, hogy az alkotmányozás tartalmi kérdéseivel egyet nem értő ellenzéki pártok - hasonlóan a NEKA-tárgyalások általában vett módszeréhez - parlamenten kívüli eszközökkel szerettek volna érvényt szerezni álláspontjuknak. Hátrahagyva az alkotmányozás feladatát, nemzetközi szervezetekkel ismertették ellenvéleményeiket. Ezzel azonban csak azokat a folyamatokat erősítették, amelyek korábban már - a konszenzus hiánya miatt - az alkotmányozás kudarcához vezettek, még olyan esetekben is, amikor a baloldali kormányok rendelkeztek alkotmányozó többséggel. A párbeszédre való hajlandóság hiánya ezért az At. elfogadását szimbolikus teherrel nehezítette el, még ha nem is az ideiglenesség terhével, ahogy ez a korábbi Alkotmány esetében történt.

Nagyköveti éveim alatt Párizsból vetettem vigyázó szemem a magyar alkotmány ügyére, és a számos feladat, amellyel szembesültem, nagyköveti visszaemlékezéseimben ${ }^{19}$ is helyet kapott. Négyéves kiküldetésem alatt nagyobb érdeklődést kapott az alkotmányozás ügye, mint a magyar uniós vagy külpolitika. A francia politikusoknak állást kellett foglalniuk, hogy miként viszonyuljanak a magyar At. egyes rendelkezéseihez (a nemzet egysége, a határokon kívül élő közösségekhez való viszony, a házasság fogalma, a kereszténység nemzetmegtartó szerepe stb., amelyek Franciaországban is

19 Trócsányi László: Párizsi Napló. Budapest, Századvég, 2018. 
égető jogi és politikai kérdések voltak már akkoriban is). Egyszerre kaptunk kritikákat és csöndes elismeréseket.

E periódusom első felében a Velencei Bizottság tagjaként (2013-ig) közvetlen rálátásom volt arra a tevékenységre is, amely az At. szövegére, majd az azzal kapcsolatban elfogadott módosításokra irányult. A jelen terjedelmi keretek között lehetetlen lenne minden vizsgált módosítással kapcsolatban minden érvet és ellenérvet felsorolni, így csak néhány kérdésre térnék ki, két csokorba szedve a tárgyalt módosításokat.

(i) Az első három tulajdonképpen technikai jellegű szövegváltoztatásokat tartalmazó módosítás után, az At. elfogadását követően 2013-ban az At. negyedik módosításával erősödött fel a nemzetközi figyelem a magyar alkotmányos rendszer müködése vonatkozásában, majd e viták nyugvópontra jutását követően került sor az ötödik módosítás elfogadására (Első felvonás).

(ii) Ezt követően, három év kihagyás után, 2016 és 2019 között fogadták el a soron következő három módosítást, és jelenleg küszöbön áll egy kilencedik (Másodikfelvonás).

\section{Első felvonás}

Először az At. körüli viták 2010 és 2013 közötti szakaszát tekinteném át röviden. E folyamatokat egész Európában politikai és ideológiai motivációk árnyalták. Elsődlegesen az egypárti alkotmányozás, a Nemzeti Hitvallás és az At. bizonyos rendelkezései voltak napirenden, de pár esetben volt példa arra is, hogy egyes nemzetközi szervezetek véleményét félreértések orientálták.

Jellegzetes példa volt (még 2011-ben) a Velencei Bizottság és a magyar állam közötti egyszerüen elkerülhető félreértésekre az, hogy a „törvény” kifejezés angol megfelelőjével kapcsolatban egy könnyedén elkerülhető fordítási hibából született konfliktus. A Bizottság kifogásai szerint az At. Európa Tanács részére megküldött angol nyelvü fordításában a „special Acts” (különleges törvények) kifejezés szerepelt az I. cikk (3) bekezdésében az alapvető jogok és kötelezettségek körében, amely nem tartalmaz bövebb iránymutatást és korlátozást e különleges törvények alkalmazási körére nézve. ${ }^{20}$

A magyar szöveget ismervén nyilvánvaló volt a fordítási hiba, és jól tudtam, hogy akkoriban három-négy párhuzamos angol nyelvủ fordítása forgott közkézen az At.nek (például Kormány, $\mathrm{AJBH}, \mathrm{AB}$ ), amely jogbiztonsági és normavilágossági szempontból nem igazán volt jó döntés, tekintettel a nemzetközi vitákra is. Az ezzel a félreértéssel kapcsolatos egyeztetések során előadtuk, hogy ebben az esetben az angol fordítás helytelen, míg a francia helyes volt, és egyértelműen az Országgyủlés által elfogadott (egyszerü) törvényekről van szó. Levontam a megfelelő következtetéseket a helyzetből, és talán ezért sem véletlen, hogy igazságügyi miniszteri programom részeként az Országos Fordító és Fordításhitelesítő Iroda tevékenységére is különös fi-

20 Council of Europe: CDL-AD(2011)016, Opinion on the New Constitution of Hungary, para. 59. 
gyelmet fordítottam, hogy a hasonló félreértéseket az At. és az annak végrehajtására született jogszabályokkal kapcsolatos nemzetközi párbeszédben elkerülhessük.

Ha már a "törvényeknél” tartunk, akkor az At. elfogadásával kapcsolatos nemzetközi viták részét képezte kezdetben a „sarkalatos törvények” kérdése is. Az elfogadáskor 39, jelenleg 32 sarkalatos törvényi tárgykört megnevező alkotmány kapcsán e tárgykörök magas száma volt a kritikák tárgya. Megjegyzendő azonban, hogy a sarkalatosság minősített többségi elfogadást jelent, és az 1949. évi alkotmányunk is 33 ilyen tárgykört tartalmazott már. Önmagában tehát az, hogy a sarkalatos törvényhozási tárgykörök száma magas, nem ok a kritikára, az egyetlen valós félelem az lehet, hogy a mindenkori kétharmados parlamenti többséggel rendelkező politikai párt képes egymaga eldönteni és alakítani e szabályok tartalmát. Ez azonban politikai ok és nem valamely jogi kritériumnak való megfelelés hiánya a jogalkotás szabályozása tekintetében. Kevésbé okozott volna talán problémát a helyzet akkor, ha az At. által elöírt kétharmados minősített többséget e szabályok elfogadásához nem egy politikai párt birtokolta volna.

Az At. elfogadását megelőző 20 évben, ahogy arra a bevezetőben is utaltam, két kormánynak volt kétharmados többsége a parlamentben, és politikai akarat esetében az összes kétharmados (sarkalatos) tárgykörben megszülettek e szabályok akkor is. De lehetséges lett volna-e az alkotmányozás ezen jogalkotás-technikai szabály kikerülésével? Erről is érdemes lett volna a Bizottság jelentésében vitát kezdeményezni vagy álláspontot elfoglalni. Vitathatatlan, hogy ebben az esetben egy jóval részletesebb, hosszabb At.-nek kellett volna születnie, de az alkotmányozó szándéka a kezdetektől egy úgynevezett magalkotmány (Kernverfassung) ${ }^{21}$ elfogadása volt, és a sarkalatos tárgykörök magas számát - amelyeket a részletszabályok meghatározására vezettek be - feltehetően a praktikum indokolta, és a tartalmilag rugalmatlan alkotmány elkerülésének igénye. A sarkalatos törvények praktikus voltára és azok ilyen számú szükségességére az elfogadott jogszabályok normatív tartalma, stabilizáló hatásuk, szerepük vonatkozásában folytatott viták tudtak és tudnak a jövőben is rávilágítani majd. (Egy példa erre az At. harmadik módosításával 2012 decemberében a termőföldtulajdon megszerzésével kapcsolatosan előírt sarkalatos törvényi szabályozás kapcsán folyt vita.) Ezekben a vitákban pedig döntő szerepe volt, van és lesz annak, hogy a politikai pártok mennyiben és milyen mértékben vesznek részt majd a jogalkotási javaslatok parlamenti vitáiban, és hogy milyen lesz a pártok közötti egyeztetések mélysége és gyakorisága. Ha konstruktivizmus és konszenzuskeresés vezeti ezeket a folyamatokat, akkor elkerülhetö, hogy az elfogadott sarkalatos törvények további kihívásokat szüljenek, amelyek a nemzetközi színtér további figyelmét is kihívhatják majd.

A parlamenti jogalkotás feletti kontroll szabályozása is beleillik azon viták összefüggéseinek ismertetésébe, amelyek az At. elfogadása kapcsán felmerültek, és azóta foglalkoztatják a nemzetközi közvéleményt. Az At. ugyanis, az azzal egyidőben hatályba lépő új Abtv. rendelkezéseivel kiegészülve, megreformálta az Alkotmánybíróság

21 Varga Zs. András: A mag-alkotmány védelmében. Pázmány Law Working Papers, (2011), 2. 1-15. 
(AB) összetételét, megválasztását, hatásköreit és eljárását is. A sarkalatos törvények sorából kiemelve a pénzügyi tárgyúakat, az At. korlátozta az $\mathrm{AB}$ az ezek felett gyakorolható utólagos normakontroll hatásköreit; megszüntetve a parttalan actio popularist, általánosságban is változtatásokat eszközölt a normakontroll-hatáskörökön és mélységében átalakította az alkotmányjogi panasz szabályozását is. ${ }^{22}$

Visszatekintve, az idő próbáját az alkotmányjogi panaszeljárások rendszerének és szabályozásának átalakítása úgy tűnik, hogy kiállja, ugyanis 2019-ben két típusú panasz esetében is úgy határozott az Emberi Jogok Európai Bírósága, ${ }^{23}$ hogy az előttük folyó eljárás szempontjából szükséges és hatékony nemzeti jogorvoslatnak minősül a közvetlen és a valódi alkotmányjogi panaszeljárás a tisztességes eljáráshoz való jogot védelmező 6 . cikkel kapcsolatos kérelmek (egyéni panaszok) vonatkozásában. Azt a tényt azonban nem szabad elfelejteni, hogy a Bíróság maga is rögzíti a Szalontay ügyben, hogy „kész megváltoztatni álláspontját a kérdéses jogorvoslatok potenciális hatékonyságával kapcsolatban, amennyiben a nemzeti hatóságok gyakorlata ezirányba mutatna". ${ }^{24}$

$\mathrm{Az}$ AB hatáskörei és eljárása kapcsán azonban még egy fontos vitapontot szeretnék említeni. Ez pedig az At. hatálybaléptetésével összefüggésben 2011. év végével elfogadott úgynevezett Átmeneti rendelkezések (Ár.) kérdése, amely nemcsak a hazai szakmai közvéleményben, ${ }^{25}$ hanem a nemzetközi porondon is vitákat váltott ki, különösen annak utóéletére tekintettel, amely az At. negyedik módosításához vezetett. Az Ár. számos rendelkezését az AB elhíresült 45/2012 (XII. 29.) sz. AB határozatában kihirdetésükre visszamenőleges hatállyal megsemmisítette, azon az alapon, hogy azok „közjogi érvényessége kérdőjeleződött meg”, és utalt arra a korábbi gyakorlatában kimunkált tételre, hogy „nem zárható ki az Alkotmánybíróság hatásköre az alkotmányi rendelkezéseknek a közjogi érvénytelenség szempontjából való felülvizsgálatára, hiszen a törvény- vagy akár alkotmányellenesen létrejött, a közjogi érvénytelenségben szenvedő jogszabályok semmisnek, vagyis olyannak tekintendőek, mintha azok létre sem jöttek volna".

Az alkotmányozó hatalom azonban úgy határozott, hogy e világos döntés ellenére a vitatott rendelkezéseket mégis elhelyezi az At. szövegében. Így született meg az At. negyedik módosítása, amellyel kapcsolatban az Európai Bizottság vizsgálatot indított (Barroso elnök levelet küldött a miniszterelnöknek), ${ }^{26}$ a Velencei Bizottság pedig különvéleményt fogadott el 2013 júniusában, ${ }^{27}$ amelynek tartalma mindenki

22 E kérdést már a Velencei Bizottság korábban idézett CDL(2011)011. számú véleménye is érintette, s a nemzetközi testület a változtatások döntő részével támogatólag egyetértett.

23 Lásd: Mendrei v. Hungary (kérelemszám: 54927/15, ítélet: 2018. július 5.), Szalontay v. Hungary (kérelemszám: 71327/13, ítélet: 2019. április 4.)

24 Lásd: Szalontay v Hungary, para. 39.

25 Lásd: bővebben: Csink Lóránt - Fröhlich Johanna: Egy alkotmány margójára - Alkotmányelméleti és értelmezési kérdések az Alaptörvényröl. Budapest, Gondolat, 2012. 140-156.

26 Vö. European Commission: The European Commission reiterates its serious concerns over the Fourth Amendment to the Constitution of Hungary. Press release, 2013.

27 Council of Europe: CDL-AD (2013)012, Opinion on the Fourth Amendment to the Fundamental Law of Hungary. 2013. 
előtt ismeretes. Az Európai Bizottsággal és a Velencei Bizottsággal folytatott közel féléves tárgyalások lezárását követően pedig megszületett az At. ötödik módosítása 2013. szeptember 16-án, azon problémák kijavítását célozva, amelyeket e nemzetközi szervezetek azonosítottak. A módosítás érintette a vallásgyakorlás, a politikai reklámok, a bírósági igazgatás és a Magyar Nemzeti Bank feladatainak egyes kérdéseit, illetve ezekkel összefüggésben hatályon kívül helyezett néhány alkotmányi rendelkezést, többek között például az OBH elnökének az ügyáthelyezésre vonatkozó jogát konkrét ügyek vonatkozásában.

E sorok írása közben már a kilencedik módosítás előszobájában vagyunk, ${ }^{28}$ kilenc évvel az At. elfogadását követően. Ezért úgy vélem, hogy nem tehetem meg, hogy nem reflektálok a viták ismertetésének intermezzójaként arra a módosítások gyakorisága kapcsán előkerülő érvre, amely az alkotmány stabilitására ${ }^{29}$ összpontosít. Ebből a szempontból egy egységként kezelem az első öt módosítást, hiszen azokat nem egészen két év alatt fogadták el az At. hatálybalépésének dátumától számítva. Az alkotmány stabilitásával és az új alkotmány szükségességével kapcsolatban magam is már számos alkalommal hivatkoztam azokra a jól ismert álláspontokra, amelyek a „folyamatos alkotmánymódosítás” ${ }^{30}$ hasonlatával írták le az 1989 és 2010 közötti folyamatokat. Ha most retrospektíven a 2010-2020 közötti időszak vonatkozásában megvizsgáljuk ezt a kérdést, ugyanezt a mintát látjuk kirajzolódni.

A viták természetesen fontosak, és akkor hatékonyak, ha párbeszédre tudnak épülni. Alkotmányos párbeszéd folyik természetesen a nemzeti intézmények között, de a nemzeti és nemzetközi intézmények között is. Ezen viták egyik központi kérdése például az volt, hogy az alkotmányozó hatalom felülírhatja-e az alkotmányértelmező hatalom által alkotmányellenesség okán megsemmisített alkotmányi rendelkezéseket (adott esetben alkotmánymódosítást) ${ }^{31}$ az alkotmány szövegébe való „bebetonozás” által. A francia Alkotmánytanács például egy döntésében kimondta, hogy „az alkotmányozó hatalom szuverén", és ennek alapján nem is csoda, hogy Franciaországban

28 A T/13647. számú törvényjavaslatot 2020 novemberében nyújtotta be az igazságügyi miniszter az At. kilencedik módosítása tárgyában.

29 Ahogy Szakály fogalmaz: „Egy adott ország alkotmányának stabilitása legalapvetőbben abban nyilvánul meg, hogy milyen gyakran változik maga az alkotmány szövege, milyen időközönként érzi szükségét az alkotmányozó/alkotmánymódosító a változtatásnak, vagyis a gyakorlati tapasztalatok alapján milyen időközönként sikerül a változtatáshoz szükséges feltételeket teljesíteni." (Szakály Zsuzsa: Az alkotmány stabilitását védő garanciák. Doktori értekezés, Szeged, 2018.)

30 Vö. Halmai Gábor: Alkotmányos értékek és demokratikus konszolidáció. Fundamentum, 13. (2009), 3. 31-48.; Balázs Zoltán: A magyar alkotmányossági trend és a 2010-11-es alkotmányozás. Jakab András - Körösényi András (szerk.): Alkotmányozás Magyarországon és máshol. Budapest, MTA TK Politikatudományi Intézet - Új Mandátum, 2012. 242-262.; Antal Attila: Politikai és jogi alkotmányosság Magyarországon. Politikatudományi Szemle, 22. (2013), 3. 56-57.

31 Az alkotmányellenes alkotmánymódosítások alkotmánybírósági felülvizsgálatának igen széles hazai és nemzetközi irodalmi bázisa van (szemelvényezi legutóbb részletesen: Szakály [2018] i. m. 177-182.), de az foglalkoztatja természetesen a nemzetközi szervezeteket is. A Velencei Bizottság tárgybeli véleményében [lásd Council of Europe: CDL-AD(2010)001 Report on constitutional amendment. 2009. para. 194-196.] leszögezi, hogy számos ország az Alkotmánybíróságok kötelező szerepvállalását rögzíti alkotmánymódosítási eljárásokban. 
az alkotmányozó hatalom számos alkalommal épített be az Alkotmánytanács által alkotmányellenessé nyilvánított szabályokat az alkotmányba. ${ }^{32}$ A 2003-as belga alkotmánymódosításról maga a Velencei Bizottság mondta azt, hogy lehet, hogy ellentétes volt az alkotmánybíróság döntésével, de attól még az alkotmányozó hatalom jogában állt a módosítás elfogadása. A Bizottság azonban azt is kifejtette, hogy ha az alkotmányozó túl gyakran lép ebbe a folyóba, akkor az alkotmányos kultúra hiányának kérdését veti fel, amely áttételesen egyébként az alkotmánybíróság tekintélyének és autoritásának megkérdőjelezéséhez is elvezet. ${ }^{33}$

\section{Második felvonás}

Az At. módosításainak 2016-2019 (2020) közötti időszakát az új típusú kihívások időszakaként aposztrofálom, amelyben azonban szintén helyet kaptak technikai jellegủ módosítások (nyolcadik) a nemzetközi vitákra reflektálva, valamint nagyobb rendszerszintű módosítások is (hatodik és hetedik). Mint igazságügyi miniszter fontosnak tartottam az At. stabilitásának megőrzését, mégis hivatali időm alatt két alkalommal sor került annak módosítására.

Az At. ebben az időszakban véghez vitt módosításainak kettős kontextusa volt, amelyekről érdemes röviden szót ejteni:

(i) Egyrészről befolyásolták azt a nemzetközi migrációs nyomásra és az ezzel párhuzamosan, de nem közvetlenül és kizárólag ebből fakadóan megnövekedett terrorizmusveszélyre - mint új típusú kihívásokra - adott európai és nemzeti válaszok, illetve az ezek kapcsán kialakult párbeszéd.

(ii) Másrészről pedig a magyar igazságszolgáltatási rendszer reformjával kapcsolatos azon elképzelés nyomán kialakult nemzetközi párbeszéd, amely az elkülönült közigazgatási bíráskodás rendszerét kívánta volt bevezetni hazánkban. Ezen folyamatokra, nagyköveti éveimet követően, számomra is új típusú kihívások keretében volt alkalmam rálátást szerezni, hiszen Magyarország igazságügyi minisztereként tevékenykedtem és voltam felelős az ezekre a kihívásokra adott jogalkotási válaszok megfogalmazásáért.

Az első fent felvázolt kontextus kapcsán fogadták el az At. hatodik módosítását 2016. június 14-én, amely a különleges jogrendi rendelkezések közé iktatta be a „ter-

32 Lásd pl.: Décision n 93-325 DC du 13 août 1993 sur la Loi relative à la maitrise de l'immigration et aux conditions d'entrée, d'accueil et de séjour des étrangers en France Décision n 98-407 DC du 14 janvier 1999 sur la Loi relative au mode d'élection des conseillers régionaux et des conseillers à l'Assemblée de Corse et au fonctionnement des Conseils régionaux.

33 Lásd: Council of Europe: CDL-AD (2012)016. Avis relatif á la révision de la Constitution de la Belgique, para. 67.; Council of Europe: CDL-AD (2013)012. Opinion on the Fourth Amendment to the Fundamental Law of Hungary, para. 78-87. 
rorveszélyhelyzet” fogalmát. ${ }^{34}$ Természetesen nem hazánk az első olyan ország, amely ezen új típusú kihívással szembesült, Franciaországban, nagyköveti megbízatásom ideje alatt, két esetben is közelről voltam tanúja súlyos terrorcselekményeknek, amelyek Toulouse-ban antiszemita, valamint Párizsban a Charlie Hebdo szerkesztősége ellen elkövetett radikális iszlamista támadások voltak..$^{35}$

Természetesen a 2010-es évek közepén Franciaországban már megindult egy olyan alkotmánymódosítási hullám, amely a különleges jogrendi helyzetek cizellálását szolgálta, és vannak nemzetközi szervezetek részéről írott elemzések, amelyek azt a magyar At. hatodik módosítása által bevezetett szabályozással párhuzamba állítva - kritikai éllel - értékelik. ${ }^{36} \mathrm{~A}$ francia szabályozás reformjának terve ${ }^{37}$ azért volt megalapozott, mert az alkotmány rendelkezései történetileg és hagyományosan ${ }^{38} \mathrm{csak}$ nagyon szűk körben engedélyezik különleges jogrendi eszközök alkalmazását, és így az vált szükségessé, hogy a 2015-ben fél évre kihirdetett szükségállapotot folyamatosan kellett meghosszabbítani, amely így magában hordozta - az egyébként alkotmányellenes - „permanens szükségállapot” kialakulásának veszélyét.

Az alkotmánymódosítás ügye ${ }^{39}$ végül jelentős nemzetközi kritikai visszhangra csak a sajtóban talált, és inkább belpolitikai konfliktusokhoz vezetett, amelyek kapcsán az igazságügyi miniszter (Christiane Taubira) lemondásra kényszerült. Végül azért bukott el az ezirányú alkotmánymódosítás, mert a rendelkezések között helyet kellett volna kapjon egy olyan rendelkezés, amely megfosztotta volna francia állampolgárságuktól a terrorizmus vádjával elítélt kettős állampolgárokat. Ezt, bár támogatták a szükségállapoti szabályok alkotmányba helyezését, a francia törvényhozás már nem

34 Ma, a kilencedik módosítás előszobájában, gazdagodva a Covid-19-pandémia (mint új típusú kihívás) és az ennek nyomán bevezetett különleges jogrend gyakorlati működésének tapasztalataival, szintén az alkotmány stabilitását érintő kérdés az is, hogy mennyiben rajzolja át a különleges jogrendi szabályozást három év múltán az újabb reform. (A különleges jogrendi tapasztalatokat a Covid-védekezés tükrében európai szinten vizsgálja: Ungvári Âlmos - Hojnyák Dávid: Az Európai Unió egyes tagállamainak koronavírus-járványra adott válasza, különös tekintettel a vizsgált államok által bevezetett különleges jogrendi szabályozásra. Miskolci Jogi Szemle, 15. (2020), 1. 122-138.

35 Bár a párizsi támadásnak kintlétem alatt nem volt halálos áldozata, 2015 januárjában ismételten bombatámadás érte az épületet, több ember halálát okozva. Személyes élményeim e merényletekkel kapcsolatban nagyban formálták azt a látásmódot, amellyel a terrorveszély mindennapi életre gyakorolt hatásához és a terrorizmus elleni küzdelem alkotmányos szabályozásához a mai napig hozzáállok. Lásd pl.: Trócsányi (2018) i. m. 219-220. (Toulouse.)

36 Olivier Duhamel: Terrorism and Constitutional Amendment in France. European Constitutional Law Review, 12. (2016), 1. 1-5.; Katalin Dobias: 6. The role of constitutional identity in the responses to the terror attacks in France and the refugee-management crisis in Hungary. In Annual Review of Constitution-Building Processes: 2015. Strömsborg, International IDEA, 2016. 101-120.; Szekeres Tamás: Európai kihívásokra válasz a terrorveszélyhelyzet Alaptörvénybe emelése. Szeged Ma, 2016.

37 Lásd: Duhamel (2016) i. m.

38 A francia szabályozás történetének elemzését lásd: Olivier Beaud - Cécile Guérin-Bargues: Létat d'urgence: Une étude constitutionnelle, historique et critique. 2é ed. L.G.D.J. - Lextenso Editions, 2018.

39 Idris Fassassi: France: The wrong path? The limits of constitutional reform in response to terrorist attacks. Constitutionnet, 2016. 
kívánta megszavazni, és a reakciókat látván Hollande elnök letett az alkotmánymódosítás ügyéről.

Hazánkban az At. különleges jogrendi rendelkezései között a módosítást megelőzően nem szerepelt hasonló rendelkezés, és bár a bevezetett terrorveszélyhelyzeti rendelkezés lényegét tekintve hasonló a szintén e rendelkezések között található megelőző védelmi helyzet logikájához (annak „belbiztonsági megfelelője”), hogy a haderő alkalmazása kapcsán jóval szűkebb felhatalmazást ad az állam biztonságának védelmébe történő beavatkozásra. A módosítás általános indokolása szerint „[a] kialakult biztonsági környezetre figyelemmel a módosítás az Alaptörvény különleges jogrendi szabályainak kiegészítését szolgálja a terrorizmus új típusú biztonsági kihívásainak megelőzése és kezelése érdekében, tekintettel arra, hogy az elmúlt időszakban az ilyen típusú - fegyveres és nem fegyveres - fenyegetések fokozódtak Európában”.40

A terrorizmus kapcsán a nemzetbiztonságot mint védendő közérdeket egy olyan kontextusban még az EUSZ 4. cikk (2) bekezdése is megemlíti, amely az At. hetedik módosítása kapcsán kulcsfontosságú kérdéssé válik Magyarországon is. Ez pedig az alkotmányjogi irodalomban „alkotmányos identitás” ${ }^{41}$ néven elhíresült fogalom kontextusa, amelynek kapcsán az EUSZ megfogalmazza, hogy az Unió „[t]iszteletben tartja az alapvető állami funkciókat, köztük az állam területi integritásának biztosítását, a közrend fenntartását és a nemzeti biztonság védelmét. İgy különösen a nemzeti biztonság az egyes tagállamok kizárólagos feladata marad." ${ }^{22}$ Talán ennek is betudható, hogy különösebb nemzetközi vita nem övezte a hatodik módosítást, ahogy a hasonló francia alkotmánymódosítási kísérleteket sem.

Az At. hetedik módosítása ${ }^{43}$ kapcsán ez azonban már nem mondható el. Az alkotmányos identitás (önazonosság) védelmére életbe léptetett alkotmányreform ugyanis számos hazai és nemzetközi vitát váltott ki, a fogalom jellegére és elméleti értékére

40 Országgyủlés Hivatala: Magyarország Alaptörvényének hatodik módosítása.

41 A teljesség igénye nélkül egy válogatás a mértékadó hazai és külföldi irodalomból: Martin Belov: The Functions of Constitutional Identity Performed in the Context of Constitutionalization of the EU Order and Europeanization of the Legal Orders of EU Member States. Perspectives on Federalism, 9. (2017), 2. 72-97.; Pietro Faraguna: Constitutional Identity in the EU - A Shield or a Sword? German Law Journal, 18. (2017), 7. 1617-1640.; Orbán Endre: Quo vadis, „alkotmányos identitás"? Közjogi Szemle, (2018), 3. 1-13.; Chronowski Nóra - Vincze Attila: Alapjogvédelem, szuverenitás, alkotmányos önazonosság: az uniós jog érvényesülésének új határai? In Chronowski Nóra (szerk.): Szuverenitás és államiság az Európai Unióban. Budapest, ELTE Eötvös Kiadó, 2017. 93-126.; Stumpf István: Alkotmányos hatalomgyakorlás és alkotmányos identitás. Budapest, Gondolat, 2020.

42 A magyar szöveget lásd: Az Európai Unióról szóló szerződés és az Európai Unió működéséről szóló szerződés egységes szerkezetbe foglalt változata.; Az elemzésről bővebben: Hermann-Josef Blanke - Stelio Mangiameli: Article 4 [The Relations Between the EU and the Member States]. In Hermann-Josef Blanke - Stelio Mangiameli (eds.): The Treaty on European Union (TEU) A Commentary. Heidelberg - New York - Dordrecht - London, Springer, 2013. 185-253.

43 A Velencei Bizottság ezzel foglalkozó véleményét lásd: Council of Europe: CDL-AD(2019)004, Opinion on the Law on Administrative Courts. 
tekintettel ezek azonban inkább a jogtudomány területére korlátozódtak. ${ }^{44} \mathrm{~A}$ módosítás végleges szövege végül nem használja magát az alkotmányos identitás kifejezést, csak annyit jelent ki, hogy „történeti alkotmányunkban gyökerező önazonosságunk védelmezése az állam alapvető kötelessége" (Hitvallás), illetve ezt konkrét normatív rendelkezés formájában kicsit másképp megfogalmazva: „Magyarország alkotmányos önazonosságának és keresztény kultúrájának védelme az állam minden szervének kötelessége." [R) cikk (4) bek.]

Ha pedig az EUSZ 4. cikk (2) bekezdésével uniós összefüggésből jutottunk el a hetedik módosítás önazonossági rendelkezéséig, akkor nem szabad megfeledkeznünk arról sem, hogy a módosítás az alkotmány úgynevezett Európa-klauzuláját is módosította, illetve további mélységi változtatásokat is eredményezett. Ezek - többek között a magán- és családi élethez való jogot, valamint az otthon nyugalmát vették védelembe a véleménynyilvánítás egyes formáival megvalósuló alapjogi kollíziókra tekintettel, illetve a bíróságok ítélkező tevékenysége vonatkozásában vezettek be teleologikus értelmezési szabályt orientáló olyan rendelkezéseket, amelyek inkább a hazai mintsem a nemzetközi szakmai közvélemény számára adtak alapot a továbbgondolásra. (Ti. „A jogszabályok céljának megállapítása során elsősorban a jogszabály preambulumát, illetve a jogszabály megalkotására vagy módosítására irányuló javaslat indokolását kell figyelembe venni." - Az At. 28. cikkének kiegészítéseként.)

A hetedik módosítás nemzetközi vitákra reflektáló és azokat kiváltó vonatkozása természetesen a bevándorlással volt összefüggésben. A magyar kormány ekkor már egy ideje nemzetközi vitákban állt az európai integráció számos szervezetével az úgynevezett relokációs kvóták vonatkozásában, amelyekre alapozva 2016 októberében a Kormány egy népszavazást is kezdeményezett, amely sikertelenül zárult. Mindazonáltal - az alacsony részvételi arány melletti nagyon magas, a kvótát elutasító válaszadási arány miatt - e kezdeményezés politikai legitimációt adott arra, hogy az újabb módosítást az Országgyủlés elé terjesszék. A szükséges parlamenti többség hiányában azonban ezt nem fogadták el, az csak ismételt szavazást követően, 2019. január 1-jén lépett hatályba.

Ne feledkezzünk meg azonban arról sem a hetedik módosítás kapcsán, hogy egy nagyon fontos feladatot is el kellett végeznünk ezzel kapcsolatban. Nevezetesen, reflektálnunk kellett az AB 2016-os gyakorlatában ${ }^{45}$ azonosított azon jogalkotói mulasztásokra, amelyek olyan helyzetekhez vezethettek, hogy az alkotmányértelmező nem tudott megfelelő egyensúlyt teremteni az úgynevezett konkuráló alapjogi pozíciókban lévő, jogaikat egymással szemben érvényesíteni kívánó jogosultakkal szemben. Így a magánélethez való jog és a véleménynyilvánításhoz való jog olyan „ütközőzónái” jöttek létre a fizikai és az online térben is, amelyek kezelésére a jogszabályi környezet, megfelelő alkotmányos alapok híján nem volt képes.

44 Legújabban lásd: Drinóczi Tímea: Constitutional Identity in Europe: The Identity of the Constitution. A Regional Approach. German Law Journal, 21. (2020), 2. 105-130.

45 Lásd pl.: 13/2016 (VII. 18.) AB határozat. 
Módosult tehát az At. VI. cikke a magánélet vonatkozásában, védelem alá helyezve az otthon nyugalmát és a családi életet, és kimondta, hogy „[a] véleménynyilvánítás szabadsága és a gyülekezési jog gyakorlása nem járhat mások magán- és családi életének, valamint otthonának sérelmével”. (Ezen az alapon már meg lehetett teremteni azokat a szakjogi szabályokat, amelyek a 2018. év során a magánéletvédelmi törvény és a gyülekezési jogról szóló törvény formájában öltöttek testet, de most nem ezek bemutatása, hanem az Alaptörvény első tíz évének értékelése a feladatom.)

2017-ben nem volt napirenden az At. módosítása, az eddig szunnyadó alkotmányos konszolidáció egy újabb szakaszába lépett, egészen addig, amíg két évvel és két héttel az utolsó módosítás után a soron következő - főként technikai módosításokat tartalmazó - szabályozással (nyolcadik módosítás) egészült ki az alkotmány. Ezt a módosítást azonban többéves, nagyívű jogalkotási munka előzte meg, azzal a céllal, hogy nemzetközi mintákra építve és nemzetközi szervezetek véleményének ${ }^{46}$ birtokában, tanácsokkal felvértezve alakítsuk ki az alapvetően francia mintára szerveződő, elkülönült közigazgatási bíráskodás intézményrendszerét. Mondhatnám, hogy igazságügyi miniszterként számomra ez nem volt új típusú kihívás, de a praxis azt mutatta, hogy igenis vannak váratlan megpróbáltatások egy olyan területen is, amelynek egy szakember saját tudományos életművének jelentős részét szenteli. ${ }^{47}$

A közigazgatási bíráskodás reformját célzó jogalkotási munkának a teret maga az At. hetedik módosítása teremtette meg egyébként azzal, hogy az At. 1., 9. és 26. cikkeibe beépítette a Közigazgatási Felsőbíróság elnökére vonatkozó szövegrészeket. A kodifikációs munkák a nemzetközi szervezetek véleménye mellett az igazságügyi tárca és Andrássy Egyetem együttmüködésében, a European Public Law Organization támogatásával szervezett nemzetközi konferencia tudományos eredményeire is épített, de a nemzetközi szakmai és alkotmányos párbeszéd eredményeit a kormányzat politikai döntése alapján nem lehetett alkalmazni, ugyanis meghatározatlan időre elhalasztották a közigazgatási bíráskodás reformját. A helyzet érdekessége, hogy mindezt az európai alkotmányos párbeszéd szellemében, reagálva a magyar jogállamisággal kapcsolatban folytatott eljárásokra tették, tehát a gyakorlat azt mutatja, hogy az egymásra odafigyelő párbeszédben rejlő kétirányú hatásmechanizmusok ${ }^{48}$ működnek, és megfelelő helyiértéken kezelve akár a nemzeti alkotmány módosításának is képesek útját állni a nemzeti intézmények szuverén döntése alapján.

46 Lásd: Council of Europe: CDL-AD(2019)004, Opinion on the Law on Administrative Courts.

47 Első munkámat a közigazgatási bíráskodásról és annak mélységi kutatásáról 1992-ben írtam (Trócsányi László: Milyen közigazgatási bíráskodást? Budapest, Közgazdasági és Jogi Könyvkiadó, 1992.), és egyik legújabb írásom is ezzel foglalkozik, immáron „jogalkotási kísérletként” aposztrofálva azt, a Magyar Jog hasábjain. [Trócsányi László: A közigazgatási bíráskodás: de lege lata és de lege ferenda - Adalék egy jogalkotási kísérlethez. Magyar Jog, 67. (2020), 2. 88-94.]

48 Kukorelli sokat idézett zárógondolata e vonatkozásban úgy szól az At. és az Unió kapcsolatáról, hogy: „A történet ebben az új államkapcsolatban is az alkalmazkodásról, az együttműködésről, a kölcsönhatásokról szól. A kétirányú hatásmechanizmusokban helye van a szuverenitást védő filozófiának is. Ha az alkalmazkodás nem egyoldalú, és nem megkésett, hanem konstruktív és előrelátó, akkor helyben vagyunk. Európában." Kukorelli István: Az Alaptörvény és az Európai Unió. Pro Publico Bono, (2013), 1. 4-11. 
Ahogy majd csak sokkal később tudjuk értékelni azt, hogy sikerrel vezetik-e be az At. nyolcadik módosításával a „napirendről levett” közigazgatási bíráskodást Magyarországon, úgy azt is csak később tudjuk majd megítélni, hogy milyen lesz az At. nemrég nyilvánosságra hozott és fentebb már említett kilencedik módosításának nemzetközi fogadtatása. Mivel a kézirat lezárása idején még csak a javaslat szövege ismeretes, ezért a végleges normaszövegről és annak hatásáról még nem lehet véleményt nyilvánítani, $\mathrm{s}$ ha ismernénk is a végleges formát, az értékelés bevezetőben már említett „rendelt ideje” még nem érkezett el.

Meggyőződésem, hogy az időszaki önértékelés azonban nemcsak az embereknek, de az államoknak és az alkotmányozóknak is fontos felelőssége, így időszakonként célszerü megállni és megnézni, hogy hova jutottunk. Nem akarom ismételni a bevezetőben leírtakat, de nagyon fontos, hogy „az alkotmány nyomában”49 haladva ez olyan értékelés legyen, amely konstruktív kritikával szemléli a szöveget, annak tartalmát és az annak elfogadása mögött megbújó lehetséges nézőpontokat.

\section{Irodalomjegyzék}

Ablonczy Bálint (szerk.): Az Alkotmány nyomában. Budapest, Elektromédia, 2011.

Antal Attila: Politikai és jogi alkotmányosság Magyarországon. Politikatudományi Szemle, 22. (2013), 3. 48-70.

Balázs Zoltán: A magyar alkotmányossági trend és a 2010-11-es alkotmányozás. In Jakab András - Körösényi András (szerk.): Alkotmányozás Magyarországon és máshol. Budapest, MTA TK Politikatudományi Intézet - Új Mandátum Kiadó, 2012. 242-262.

Balogh Elemér (szerk.): Számadás az Alaptörvényrôll. Budapest, Magyar Közlöny- és Lapkiadó Kft., 2016.

Chronowski Nóra - Vincze Attila: Alapjogvédelem, szuverenitás, alkotmányos önazonosság: az uniós jog érvényesülésének új határai? In Chronowski Nóra (szerk.): Szuverenitás és államiság az Európai Unióban. Budapest, ELTE Eötvös Kiadó, 2017. 93-126. Online: www.eltereader. hu/media/2017/09/Chronowski-Szuverinitas_READER.pdf

Csink Lóránt - Fröhlich Johanna: Egy alkotmány margójára - Alkotmányelméleti és értelmezési kérdések az Alaptörvényröl, Budapest, Gondolat, 2012.

Beaud, Olivier - Cécile Guérin-Bargues: Létat d'urgence: Une étude constitutionnelle, historique et critique. 2é ed. L.G.D.J. - Lextenso Editions, 2018.

Belov, Martin: The Functions of Constitutional Identity Performed in the Context of Constitutionalization of the EU Order and Europeanization of the Legal Orders of EU Member States. Perspectives on Federalism, 9. (2017), 2. 72-97. Online: https://doi.org/10.1515/pof-2017-0010

Blanke, Hermann-Josef - Stelio Mangiameli: Article 4 [The Relations Between the EU and the Member States]. In Hermann-Josef Blanke - Stelio Mangiameli (eds.): The Treaty on European Union (TEU) A Commentary. Heidelberg - New York - Dordrecht - London, Springer, 2013. 185253. Online: https://link.springer.com/chapter/10.1007/978-3-642-31706-4_5

Dobias, Katalin: 6. The role of constitutional identity in the responses to the terror attacks in France and the refugee-management crisis in Hungary. In Annual Review of Constitution-Building

49 Lásd: Ablonczy Bálint (szerk.): Az Alkotmány nyomában. Budapest, Elektromédia, 2011. 
Processes: 2015. Strömsborg, International IDEA, 2016. 101-120. Online: www.idea.int/sites/ default/files/publications/chapters/annual-review-of-constitution-building-processes-2015/ annual-review-of-constitution-building-processes-2015-chapter-6.pdf

Drinóczi Tímea: Constitutional Identity in Europe: The Identity of the Constitution. A Regional Approach. German Law Journal, 21. (2020), 2. 105-130. Online: https://doi.org/10.1017/glj.2020.1

Duhamel, Olivier: Terrorism and Constitutional Amendment in France. European Constitutional Law Review, 12. (2016), 1. 1-5. Online: https://doi.org/10.1017/s1574019616000067

European Commission: The European Commission reiterates its serious concerns over the Fourth Amendment to the Constitution of Hungary. Press release, 2013. Online: https://ec.europa.eu/ commission/presscorner/detail/en/IP_13_327

Faraguna, Pietro: Constitutional Identity in the EU - A Shield or a Sword? German Law Journal, 18. (2017), 7. 1617-1640. Online: https://doi.org/10.1017/s207183220002246x

Fassassi, Idris: France: The wrong path? The limits of constitutional reform in response to terrorist attacks. Constitutionnet, 2016. Online: http://constitutionnet.org/news/france-wrong-path-limits-constitutional-reform-response-terrorist-attacks

Halmai Gábor: Alkotmányos értékek és demokratikus konszolidáció. Fundamentum, 13. (2009), 3. 31-48.

Kukorelli István: Az Alaptörvény és az Európai Unió. Pro Publico Bono, (2013), 1. 4-11. Online: https://folyoirat.ludovika.hu/index.php/ppbmk/article/view/3129/2379

Orbán Endre: Quo vadis, „alkotmányos identitás”? Közjogi Szemle, (2018), 3. 1-13. Online: https:// hvgorac.hu/tallozo/Orban_Endre_Quo_vadis_alkotmanyos_identitas

Stumpf István: Alkotmányos hatalomgyakorlás és alkotmányos identitás. Budapest, Gondolat, 2020. Sulyok Márton - Trócsányi László: Preambulum. In Jakab András (szerk.): Az Alkotmány kommentárja. 2. kiadás, Budapest, Századvég, I. kötet, 2009. 52-60.

Szakály Zsuzsa: Az alkotmány stabilitását védő garanciák. Doktori értekezés, Szeged, 2018. Online: https://doi.org/10.14232/phd.9702

Szekeres Tamás: Európai kihívásokra válasz a terrorveszélyhelyzet Alaptörvénybe emelése. Szeged $M a$, 2016. Online: https://szegedma.hu/2016/01/europai-kihivasokra-valasz-a-terrorveszelyhelyzet-alaptorvenybe-emelese

Trócsányi László: Milyen közigazgatási bíráskodást? Budapest, Közgazdasági és Jogi Könyvkiadó, 1992.

Trócsányi László: Az alkotmányozás dilemmái. Alkotmányos identitás és európai integráció. Budapest, HVG-ORAC, 2014.

Trócsányi László: Nemzeti alkotmányok, európai integráció és alkotmányos identitás. In Tóth Judit (szerk.): Tanulmányok Dr. Tóth Károly címzetes egyetemi tanár 70. születésnapjára. Szeged, Szegedi Tudományegyetem, 2015. 319-328. Online: http://acta.bibl.u-szeged.hu/45281/1/juridpol_078_319-328.pdf

Trócsányi, László: The Dilemmas of Drafting the Hungarian Fundamental Law. Constitutional Identity and European Integration. Passau, Schenk Verlag, 2016.

Trócsányi László: Az Alaptörvény értékrendje. In Vízkelety Mariann (főszerk.): 5 éves az Alaptörvény. Válogatás az ünnepi konferenciasorozat beszédeiböl. Budapest, Magyar Közlöny- és Lapkiadó, 2017. 108.

Trócsányi László: Párizsi Napló. Budapest, Századvég, 2018.

Trócsányi László: A közigazgatási bíráskodás: de lege lata és de lege ferenda - Adalék egy jogalkotási kísérlethez. Magyar Jog, 67. (2020), 2. 88-94. 
Trócsányi, László - Márton Sulyok: The Birth and Early Life of the Basic Law of Hungary. In András Zs. Varga - András Patyi - Balázs Schanda (eds.): The Basic (Fundamental) Law of Hungary: A Commentary of the New Hungarian Constitution. Clarus Press, 2015. 1-10. Online: http://m. ludita.uni-nke.hu/repozitorium/bitstream/handle/11410/10136/The\%20Basic\%20Law\%20 of\%20Hungary.pdf?sequence $=1$ \&isAllowed $=y \% 2075$

Ungvári Álmos - Hojnyák Dávid: Az Európai Unió egyes tagállamainak koronavírus-járványra adott válasza, különös tekintettel a vizsgált államok által bevezetett különleges jogrendi szabályozásra. Miskolci Jogi Szemle, 15. (2020), 1. 122-138. Online: http://mfi.gov.hu/wp-content/ uploads/2020/07/Miskolci-Jogi-Szemle_Hojny\%C3\%A1k-Ungv\%C3\%A1ri_t\%C3\%B6rdelt.pdf

Varga Zs. András: A mag-alkotmány védelmében. Pázmány Law Working Papers, (2011), 2. 1-15. Online: https://plwp.eu/docs/wp/2012/2011-02.pdf

Visser, Maartje de: A Critical Assessment of the Role of the Venice Commission in Processes of Domestic Constitutional Reform. American Journal of Comparative Law, 63. (2015), 4. 9631008. Online: https://doi.org/10.5131/ajcl.2015.0029

\section{Jogforrások}

13/2016 (VII. 18.) AB határozat

CDL-AD(2011)001 (28 March 2011) on Three Legal Questions Arising in the Process of Drafting the New Constitution of Hungary and CDL(2011)032 (6 June 2011) Draft Opinion on the New Constitution of Hungary.

Council of Europe: CDL-AD(2013)018-e, Opinion on the balance of powers in the Constitution and the Legislation of the Principality of Monaco. 2013. Online: www.venice.coe.int/webforms/ documents/default.aspx?pdffile=CDL-AD(2013)018-e

Council of Europe: CDL-AD(2011)016, Opinion on the New Constitution of Hungary. Online: www.venice.coe.int/webforms/documents/default.aspx?pdffile=CDL-AD(2011)016-e

Council of Europe: CDL-AD(2010)001 Report on constitutional amendment. 2009. Online: www. venice.coe.int/webforms/documents/?pdf=CDL-AD(2010)001-e

Council of Europe: CDL-AD (2012)016, Avis relatif á la révision de la Constitution de la Belgique. 2012.

Council of Europe: CDL-AD (2013)012, Opinion on the Fourth Amendment to the Fundamental Law of Hungary. 2013. Online: www.venice.coe.int/webforms/documents/default.aspx?pdffile=cdl$\operatorname{ad}(2013) 012-\mathrm{e}$

Council of Europe: CDL-AD(2019)004, Opinion on the Law on Administrative Courts. Online: www.venice.coe.int/webforms/documents/default.aspx?pdffile=CDL-AD(2019)004-e

Décision n 93-325 DC du 13 août 1993 sur la Loi relative à la maîtrise de l'immigration et aux conditions d'entrée, d'accueil et de séjour des étrangers en France

Décision n 98-407 DC du 14 janvier 1999 sur la Loi relative au mode d'élection des conseillers régionaux et des conseillers à l'Assemblée de Corse et au fonctionnement des Conseils régionaux

European Parliament: European Parliament resolution of 5 July 2011 on the Revised Hungarian Constitution. Online: www.europarl.europa.eu/doceo/document/TA-7-2011-0315_EN.html

European Parliament: Tavares Report. 2013. Online: www.europarl.europa.eu/doceo/ document/A-7-2013-0229_EN.html?redirect

Az Európai Unióról szóló szerződés és az Európai Unió működéséről szóló szerződés egységes szerkezetbe foglalt változata. Online: https://eur-lex.europa.eu/legal-content/HU/TXT/ HTML/?uri=CELEX:12012M/TXT\&from=HU 
Országgyülés Hivatala: Magyarország Alaptörvényének hatodik módosítása. Online: www.parlament.hu/irom40/10416/10416.pdf

T/13647. számú törvényjavaslat Magyarország Alaptörvényének kilencedik módosításáról. Online: www.parlament.hu/irom41/13647/13647.pdf 